\title{
Profitability measures of dairy cows
}

\author{
Anamaria Cândido Ribeiro', Alan Jackson McAllister², Sandra Aidar de Queiroz ${ }^{3}$ \\ ${ }^{1}$ Centro Regional Universitário de Espírito Santo do Pinhal - UNIPINHAL, Espírito Santo do Pinhal, SP, Brazil, CEP: $13990-000$ - Consultant \\ for Capritec Ltda. \\ 2 Department of Animal Sciences, University of Kentucky, USA. \\ ${ }^{3}$ Departamento de Zootecnia, Universidade Estadual Paulista, Campus de Jaboticabal, SP, Brazil. Bolsista do CNPq.
}

\begin{abstract}
This study was aimed at defining profitability measures designed for prediction of breeding values (EBV) in dairy cows. Performance and economic data recorded in herds enrolled in the DHIA (Dairy Herd Improvement Association) program in Kentucky, USA, were used to evaluate economic functions which included the following profitability measures: lifetime net income (LNI), efficiency (EF), milk income over feed costs (IOFC), net income per day of productive life (NIPL), net income at the end of the first lactation (NI1), and milk income over feed costs at the end of the first lactation (IOFC1). The estimated averages for LNI, EF, IOFC, NIPL, NI1 and IOFC1 were respectively US $\$ 532.13,1.04$, US $\$ 3038.19$, US \$ - 0.16 , US \$ -69.34 and US $\$ 1293.77$. The heritability estimates for these traits ranged from 0.06 to 0.09 . The EBV and Spearman correlation estimates were positive, ranging from moderate to high values, suggesting a direct linear relationship among the profitability measures. LNI was the best profitability measure and genetic correlation estimates between LNI and economic measures recorded in first lactation (NI1 and IOFC1) were moderate $(<0.56)$. NI1 was the most efficient profitability measure, but it would be easier to record data to calculate IOFC1. Overall, results do not suggest any economic function measured in the first lactation as a selection criteria for LNI. The profitability measures were affected by the short productive life of the animals in the herds. Selection based on different profitability measures would not result in similar ranking of sires.
\end{abstract}

Key Words: efficiency, Holstein, lifetime income, milk yield

\section{Medidas de rentabilidade de vacas leiteiras}

RESUMO - Os objetivos neste trabalho foram definir funções econômicas para vacas leiteiras, classificar os animais por seus valores genéticos estimados (EBV) para cada uma destas medidas de rentabilidade e estimar correlações entre esses valores. As informações utilizadas foram provenientes de rebanhos participantes do programa da DHIA (Dairy Herd Improvement Association), em Kentucky, Estados Unidos. As características estudadas foram receita líquida vitalícia (LNI), eficiência (EF), receita do leite menos o custo de alimentação (IOFC), receita líquida por dia de vida produtiva (NIPL), receita líquida ao final da primeira lactação (NI1) e receita do leite menos o custo de alimentação ao final da primeira lactação (IOFC1). Os valores médios estimados foram US\$ 532,13; 1,04; US\$3038,19; US\$-0,16; US\$ -69,34; e US\$1293,77, respectivamente para LNI, EF, IOFC, NIPL, NI1 e IOFC1. As estimativas de herdabilidade variaram de 0,06 a 0,09. As correlações entre EBV e as de Spearman foram positivas, com valores moderados a altos, o que sugere relação linear direta entre as variáveis. As correlações estimadas entre EBV de LNI, função mais completa, e NI1 e IOFC1 foram moderadas $(<0,56)$. A medida de rentabilidade mais próxima à LNI foi IOFC, que poderia ser utilizada como critério de seleção para LNI. As características mensuradas na primeira lactação não foram completamente apropriadas como critérios de seleção. Entre essas características, NI1 foi a mais eficiente, mas IOFC1 poderia ser utilizada em programas de melhoramento, em virtude da facilidade na coleta de informações. A curta vida produtiva dos animais influenciou significativamente as medidas de rentabilidade. Além disso, as medidas de rentabilidade estudadas não produziram o mesmo resultado, pois alguns reprodutores selecionados mudariam de posição dependendo do critério adotado.

Palavras-chave: eficiência, Holandês, produção de leite, receita vitalícia

\section{Introduction}

In animal breeding, the desired goal is understood to be the breeding objective. The traits measured in the individuals and correlated with the objective define the selection criteria. Profitability measures may be used as selection criteria to estimate the economic worth of dairy cows. Nevertheless, the measurements must be as easy and inexpensive as

Este artigo foi recebido em 4/12/2006 e aprovado em 2/4/2008.

Correspondências devem ser enviadas para saquei@fcav.unesp.br. 
possible (Hammond, 1992). Therefore, the profitability functions should be sufficiently complete to distinguish the best cows, but make data recording as simple as possible. Traits that appear early in the life of the animal allow earlier decision-making, thereby decreasing the length of stay of unproductive animals in the herd and also the generation interval.

There are two main perspectives by which the profitability of a dairy cow can be approached as goals to be maximized: profit and efficiency. The profit function expressed as income minus costs gives a net economic effect of input and output items (Pearson \& Miller, 1981). The preferred functions for dairy cattle are mainly expressed per day or per year of herd life. Profit is probably the perspective desired by individual breeders (Barwick, 1992). An advantage of the economic efficiency measure over the profit function is the independence of the unit used to compute income and expenses (Weller, 1994). In addition, the economic efficiency measure allows the comparison of different types of production systems. Goddard (1992) pointed out that the proposal of the profit function is not only to predict profit, but also to show how genetic change in a trait causes a change in profit.

Estimates of net income based on information from the DHI (Dairy Herd Improvement) records may exclude certain items of expenses and income, because they may not be available (Cassell et al., 1993). However, a genetic correlation of 0.95 between net income estimates using data from DHI and data including more detailed information was reported by Tigges et al. (1986). They concluded that the information from the DHI data was adequate and sufficient for such estimates. However, Weigel et al. (1995a,b) argued that despite of profit is not directly measured by the DHI, it could be estimated by functions of variables recorded by this organization.

The objectives of this study were to evaluate economic functions to define profitability measures and to estimate genetic parameters and breeding values for the economic worth of dairy cows; and also to evaluate the usefulness of these functions in breeding programs.

\section{Material and Methods}

Performance and economic records from the DHIA (Dairy Herd Improvement Association) program in Kentucky, USA, consisted of 357,045 lactations from 140,139 Holstein cows (37,784 without pedigree information), progeny of 7,161 sires, in 968 herds characterized by an intensive management of the production system. Performance data and samples for protein, fat and somatic cell count analyses were recorded on a monthly basis. Three distinct and interdependent activities were typical in most dairy farms enrolled in the DHI program: forage production, rearing of young animals and milk production (Renkema \& Stelwagen, 1979).

Consistency of data was evaluated and edits were done for: 1) birth year of animals between 1986 and 1995, 2) animals culled between 1989 and 1998,3) productive life larger than 60 days, 4 ) information on the first lactation or on an intermediate lactation, 5) information on the value of milk or of feed costs, 6) animals recorded in just one herd, 7) body weight under $300 \mathrm{~kg}, 8$ ) age at calving between 500 and 1850 days (for first calving) or over 6000 days (other calving), 9) lactation periods over 60 days, 10) herds with at least 10 lifetime productions per year, 11) sires with at least 10 daughters with complete production records and 12) information on fat and protein production.

Only data from cows with productive life information and a valid code for culling were used in the analyses. Productive life was obtained by the number of days between date of culling and date of first calving. All records on production as well as on revenues and costs were summed for each cow, defining the lifetime and the profitability per cow estimates. Only milk yield was considered in this study, with pregnant heifers assumed to have been bought at market prices. Afterchecking for consistency and restrictions, the data set had information on 19,565 lifetime records.

The items utilized in the formulas were as follows:

Lifetime income $=$ (lifetime milk yield, considering volume and protein and fat content $x$ value of $\mathrm{kg}$ of milk that accounts for protein and fat levels) + (number of calves produced $x$ market value of the calf) + (carcass weight of the cow at culling, in $\mathrm{kg} \mathrm{x}$ value of $\mathrm{kg}$ of carcass). A bonus of $50 \%$ was added to the carcass weight of animals sold for dairy. Similarly a bonus of $20 \%$ was added to the carcass weigh of animals culled due to low production and for registered animals sold as dairy cows. The carcass weight was defined by the last calving weight in the DHI records.

Lifetime cost $=($ female value at birth $)+($ age at first calving in days $\mathrm{x}$ rearing cost of heifer from birth to first calving, per day $)+[$ (body weight of the cow $\mathrm{x}$ feed costs for maintenance $)+($ milk yield $x$ feed cost for production $)+$ (number of pregnancies $\mathrm{x}$ feed costs for pregnancy)] $\mathrm{x}$ number of lactations $+[$ (days in lactation + dry days $) x$ fixed cost] + (lifetime milk yield $\mathrm{x}$ average fixed cost for $\mathrm{kg}$ of milk produced $)+($ number of services $x$ cost of service $)+($ number of mastitis cases $x$ cost of case) + (number of calvings with little aid $x$ cost of intervention of little aid) + (number of 
calvings with moderate aid $x$ cost of intervention of moderate aid) + (number of calvings with Cesarean surgery $x$ cost of the Cesarean surgery) + cost of pedigree registration (for registered cows).

Lifetime milk income $=($ lifetime milk yield, considering volume and protein and fat content $\mathrm{x}$ value of $\mathrm{kg}$ of milk, with the levels of protein and fat already factored in)

Lifetime cost of feeding $=[$ (body weight of the cow $x$ feed costs for maintenance $)+($ milk yield $x$ feed costs for production) $\mathrm{x}$ number of lactation] + (number of pregnancies $\mathrm{x}$ feed costs per pregnancy).

The following functions were utilized for the analysis of profitability of the animals, with monetary units expressed in U.S. dollars (US\$):

1) Lifetime net income (LNI):

$\mathrm{LNI}=\mathrm{Li}-\mathrm{Lc}$, for $\mathrm{Li}=$ lifetime income $\mathrm{Lc}=$ lifetime cost.

2) Efficiency $(E F): \quad E F=\frac{L i}{L c}$

3) Lifetime milk income over lifetime feed costs (IOFC):

$$
\mathrm{IOFC}=\left[\begin{array}{l}
\sum_{\mathrm{i}=1}^{\mathrm{n}} \mathrm{Mi}(\mathrm{i}) \\
\sum_{\mathrm{i}=1}^{\mathrm{n}} \mathrm{Fc}(\mathrm{i})
\end{array}\right]
$$

for $\mathrm{i}=$ lactation number; $\mathrm{Mi}=$ income from milk and additional values for protein and fat, per lactation; $\mathrm{Fc}=$ feed costs, per lactation.

4) Net income per day of productive life (NIPL): $\mathrm{NIPL}=\frac{\mathrm{Li}-\mathrm{Lc}}{\mathrm{PL}}$

for $\mathrm{Li}$ and $\mathrm{Lc}$ as defined above and $\mathrm{PL}=$ productive life, in days.

5) Net income at the end of the first lactation (NI1): $\mathrm{NI} 1=\mathrm{I} 1-\mathrm{C} 1$, for $\mathrm{I} 1=$ income at the end of the first lactation; $\mathrm{C} 1=$ cost at the end of the first lactation.

6) Milk income over feed costs, at the end of the first lactation (IOFC1):

$$
\text { IOFC1 = Mi1 - Fc1 }
$$

for Mi1 = milk income of the first lactation; Fc1 = feed costs of the first lactation.

The payments for land and manager were not computed in the costs. Prices used for feed costs for maintenance, pregnancy and production were obtained from the literature (Isaacs and Foley, 1993; Kulak, 1994; Weigel et al., 1995b; Norman et al., 1996; Jagannatha et al., 1998), and compared to data from McAllister (2000).

The fixed costs included labor costs, remuneration for construction and equipment, repairs, depreciation, general veterinary costs, taxes, electricity, insurance and others.

Cost per mastitis case included veterinary bills, medications, labor and discarded milk, in addition to the decrease in the value of the cow for future sale. Mastitis cases were arbitrarily assigned, charging a fee each test-day that the cow scored a somatic cell count over 6 ( similar to a count over 800,000 cells per $\mathrm{ml}$ ). The average fixed cost per $\mathrm{kg}$ of milk produced took into account the costs for equipment, construction and labor help, especially associated with milking.

The values used in the income and expenses items are provided in Table 1.

Variance components, genetic parameters and EBVs for milk yield and each one of the economic traits were estimated by an animal model, using the MTDFREML program (Boldman et al., 1993), assuming $10^{-9}$ as the convergence criterion.

In matrix notation, the general model used in each univariate analysis was:

$$
\mathrm{y}=\mathrm{X} \beta+\mathrm{Za}+\mathrm{e}
$$

where: $y=$ dependent variable; $\beta=$ vector of fixed effects; $\mathrm{a}=$ vector of additive direct genetic effects; $X=$ incidence matrix associated with fixed effects; $Z=$ incidence matrix associated with random effects; and $\mathrm{e}=$ vector of errors.

This model assumes the following:

$\mathrm{E}(\mathrm{y})=\mathrm{X} \beta ; \mathrm{E}(\mathrm{a})=0 ; \mathrm{E}(\mathrm{e})=0 ; \operatorname{Var}[\mathrm{a}]=\mathrm{A} \sigma_{\mathrm{a}}^{2} ; \mathrm{e} \operatorname{Var}[\mathrm{e}]=\mathrm{IN} \sigma_{\mathrm{e}}^{2}$ for: $\mathrm{A}=$ numerator of relationship matrix; $\sigma^{2}{ }_{\mathrm{a}}=$ additive

Table 1 - Monetary values (US\$) for the items of income and expenses for Holstein dairy cows, in Kentucky, USA

\begin{tabular}{lc}
\hline Item & Value (US\$) \\
\hline Market value per calf (male or female) & 50.00 \\
kg value of live weight (culled cow) & 0.83 \\
Price of raising a heifer from birth & 1.10 \\
to first calving, per day & \\
Fixed cost, per day & 1.50 \\
Average fixed cost per kg of milk produced & 0.04 \\
Cost per service & 20.00 \\
Cost per mastitis case & 100.00 \\
Cost of intervention with little aid at calving & 60.00 \\
Cost of intervention with moderate aid at calving & 100.00 \\
Cost of Cesarean surgery & 200.00 \\
Cost of pedigree registration & 20.00 \\
\hline
\end{tabular}

Information taken from Pearson and Freeman (1973), Isaacs and Foley (1993), Kulak et al. (1997a and 1997b), Weigel et al. (1995b), Norman et al. (1996) and Jagannatha et al. (1998). The information was also checked according to McAllister (2000). 
genetic variance; $\sigma^{2}{ }_{\mathrm{e}}=$ residual variance; $\mathrm{I}=$ identity matrix; and $\mathrm{N}=$ number of observations.

The contemporary groups were defined as cows born in the same year, from 1986 to 1995, and season (Summer: July, Aug., Sept.; Fall: Oct., Nov., Dec.; Winter: Jan., Feb., March and Spring: Apr., May, June). The herd effect was not added to the contemporary groups due to the structure of the data set.

The variables LNI, EF and IOFC were analyzed including the fixed effects of herd, contemporary group, culling reasons (foot or leg problem, sold for dairy purposes, low milk yield, reproductive problems, injuries or other causes, death, mastitis, illnesses in general and udder problems), number of calvings (1-6 or more) within productive life classes, registration status (registered or grade) and linear and quadratic effects of body weight, in $\mathrm{kg}$.

The model for NIPL included the fixed effects of herd, contemporary group, reasons for culling (foot and leg problem, sold for dairy purposes, low milk production, reproductive problems, injuries or other causes, death, mastitis, illnesses in general and udder problem), number of calvings (1-6 or more) within age at culling classes, registration status and linear and quadratic effects of body weight, in $\mathrm{kg}$.

The fixed effects included in the models for NI1 and IOFC1 were herd, contemporary group, registration status and classes of days in lactation (1-3).

The model for lifetime milk yield (MY) included the fixed effects of herd, contemporary group, number of calvings (1-6 or more), registration status, classes of days in lactation (1-8) and linear and quadratic effect of body weight, in $\mathrm{kg}$.

The fixed effects included in the model for MY1 were herd, contemporary group, registration status, classes of days in lactation (1-3) and linear effect of age at first calving, in days.

The model for PL included the fixed effects of herd, contemporary group, number of calvings (1-6 or more), registration status, number of mastitis cases (zero, 1-10 or more) and linear and quadratic effects of milk yield, in $\mathrm{kg}$.

The correlation between EBV of each pair of traits and the rank correlation were estimated by the procedures CORR (Pearson) and CORR (Spearman) of SAS ${ }^{\circledR}$ (1996). The purpose of using rank correlation was to verify coincidence in the classification of the animals by their EBV through different profitability and production measures. The procedure to estimate a genetic (co)variance using a linear adjustment of the (co)variance between EBV for two traits has been described by Calo et al. (1973) and was applied to avoid the lack of convergence in the genetic correlation estimates analyses when two traits show strong correlation.

As LNI was the most complete profitability measure in this study, it was assigned as the breeding objective. In order to determine which animals would be selected by LNI and if these animals would also be selected by other criteria, they were classified into deciles classes. The aim of this approach was to compare the position of the top $10 \%$ sires evaluated by their EBV for LNI and if they would still be among the top $10 \%$ sires by other criteria. In this case, there were coincidences in decile 1 (Decile $1-1$ ) when the same animals were selected by both criteria. In addition, the shift of animals from decile 1 for the trait LNI to other deciles by other criteria was verified (Decile $1-2$, Decile $1-3$, etc). Percentages of non-coincidence should be interpreted as the proportion of animals that would not be selected by one selection criterion when utilizing the other and vice versa.

\section{Results and Discussion}

The overall means of the economic and performance traits, along with the respective standard deviation and minimum and maximum values, are presented in Table 2.

LNI was positive (US\$ 532.13) and its large standard deviation indicate the variability of this profitability measure. Such variation is partially due to the differences among cows on their length of productive live. LNI computed records of cows that produced just a few months after the first calving, up to about 10 years of productive life. This result is similar to those obtained by de Haan et al. (1992) and by Cassel et al. (1993) for animals that had an opportunity for herd life of 72 months. Such values were lower than those reported in other studies (Kulak et al., 1997a, b; Weigel et al., 1995a; Norman et al., 1996; Weigel et al., 1997; Jagannatha et al., 1998). Nonetheless, these authors did not compute the cost of the mastitis cases nor those requiring aid for difficult calvings. Therefore, because the computation of income and expenses items does not always contain the same variables, direct comparison of these values is precluded.

Among the profitability measures evaluated in this study, LNI was the most complete because it considers most of the costs and all the income of the cow throughout its life. Positive values of LNI indicate success despite the short productive life of some animals.

The EF mean (1.04) was larger than unity, indicating that the incomes were proportionally larger than the costs 
Table 2 - Overall means, standard deviation (SD), minimum (Min) and maximum (Max) values of the traits of Holstein cows in Kentucky, USA

\begin{tabular}{|c|c|c|c|c|}
\hline Trait & Mean & SD & Min & $\operatorname{Max}$ \\
\hline LNI (US\$) & 532.13 & 1270.15 & -3902.81 & $10,289.85$ \\
\hline $\mathrm{EF}$ & 1.04 & 0.23 & 0.13 & 2.18 \\
\hline IOFC (US\$) & 3038.19 & 2459.26 & -1412.00 & $18,310.00$ \\
\hline NIPL (US\$) & -0.16 & 2.33 & -21.28 & 40.66 \\
\hline NI1 (US\$) & -69.34 & 542.81 & -3966.00 & 4064.00 \\
\hline IOFC1 (US\$) & 1293.77 & 653.94 & -2341.00 & 5835.00 \\
\hline MY (kg) & $16,740.47$ & $12,883.12$ & 225.00 & $105,711.00$ \\
\hline $\mathrm{FY}(\mathrm{kg})$ & 590.71 & 456.13 & 6.00 & 3260.00 \\
\hline PY (kg) & 541.30 & 412.82 & 7.00 & 3155.00 \\
\hline MY1 (kg) & 6935.02 & 3027.67 & 159.00 & $18,313.00$ \\
\hline AFC (days) & 856.97 & 120.01 & 501.00 & 1816.00 \\
\hline PL (days) & 779.91 & 555.13 & 60.00 & 3692.00 \\
\hline $\mathrm{BW}(\mathrm{kg})$ & 576.20 & 69.19 & 318.00 & 907.00 \\
\hline № calving & 2.30 & 1.34 & 1.00 & 10.00 \\
\hline № mastitis cases & 1.26 & 2.24 & 0.00 & 32.00 \\
\hline № services & 5.06 & 3.44 & 1.00 & 24.00 \\
\hline Feed (US\$) & 1915.37 & 1499.94 & 10.00 & $13,391.00$ \\
\hline
\end{tabular}

LNI = Lifetime net income; EF = Lifetime efficiency; IOFC = Milk income over feed costs; NIPL = Net income per day of productive life; NI = Net income at the end of first lactation; IOFC1 = Milk income over feed costs at the end of first lactation; $M Y=$ Lifetime milk yield; $F Y=$ Lifetime fat yield; $P Y=$ Lifetime protein yield; $\mathrm{MY} 1=$ Milk yield in first lactation; $\mathrm{AFC}=$ Age at first calving; $\mathrm{PL}=$ Productive life; BW = Body weight; $\mathrm{N}$. of calvings, $\mathrm{N}$. of mastitis cases, $\mathrm{N}$ : of services and feed (US\$) are referred to as lifetime sums.

and so the economic viability. This measure indicates the economic yield obtained per monetary unit invested and this result reflects a narrow margin. This result is less promising though, considering that remuneration for land and capital invested was not included in the costs, nor was the return to management for the enterprise. Kulak et al. (1997b) reported a higher EF of 1.26, for cows in experimental herds in Canada.

IOFC reflects the income from the milk produced less feed costs. Its mean was US\$3038.19, higher than the value of US\$2714.39 reported by Kulak et al. (1997b), but lower than that by Klassen et al. (1992) of US\$ 4640.00, both in Canada. IOFC does not account for all revenue and cost items, but indicates the profitability per cow, considering that feeding represents about half of the production costs of dairy cows (Isaacs \& Foley, 1993).

NIPL represents the net income per day of productive life. Its mean estimate was negative, even though LNI as well as PL were positive. This could be explained by the large variation in both of the traits that they test, as the mean of NIPL did not result from the ratio of LNI and PL means. NIPL mean was calculated as the average from individually values of LNI and PL for each cow.

NI1 represents the net income at the end of the first lactation or at culling, when assuming the cow had not concluded the first lactation. As the cost of raising the heifer is computed in this measure, the mean was negative (NI1 = US\$ -69.34), even though cows culled in the first lactation received the income of their carcass value. The value of NI1 indicates that only one lactation does not generate enough revenue to cover the costs of raising the heifer, but only the costs involved in the first lactation. Jagannatha et al. (1998) showed a lower value for NI1 (US\$ -127.57), while Gill \& Allaire (1976) and Lin \& Allaire (1977) obtained positive values (US\$ 18.00 and US\$336.00, respectively).

IOFC1 is milk income minus the feed costs at the end of the first lactation, without computing the feed costs up to the first calving. The mean value obtained was US\$1293.77. It seems that IOFC1 represented $42.5 \%$ of the lifetime measure IOFC. This result was probably due to the low value of PL in the present study.

The mean for MY1 was about 7,000 kg, which may be considered high. This value is similar to that reported by de Haan et al. (1992). Short \& Lawlor (1992) reported higher values, using milk production adjusted to equivalent maturity and 305 days. The estimated mean of MY1 was also higher than that reported by Gill \& Allaire (1976). MY was $16,740 \mathrm{~kg}$, slightly lower than that reported by Klassen et al. (1992). Similar results were observed for Lifetime Protein Yield and Lifetime Fat Yield.

The mean PL was 779.81 days and represented the period in which the cow would be potentially producing revenues. On the other hand, the period in which a cow was not producing revenues (up to the first calving), was much longer, with a mean of 856.97 days (AFC). The value obtained for PL was similar to those reported by de Haan et al. (1992), Cassell et al. (1993) and Jagannatha et al. (1998), which was 
still less that those values obtained by van Arendonk (1991), Kulak et al. (1997a), Weigel et al. (1995a) and Norman et al. (1996). The results from simulations for optimal PL at 44 months in Holstein cows and at 76 months in Holstein $\mathrm{x}$ Zebu crossbreed cows in Brazil reported by Cardoso et al. (1999a and 1999b), confirmed the importance of a longer productive life to obtain better economic results.

The low estimate of PL indicated a rapid turnover of cows in the herds providing data for this study. Although this turnover may result in some genetic gain in traits of the selection objective, it does not seem to have an advantage from an economic perspective. It is very likely that the values of the profitability measures obtained in this study, sometimes lower than those reported in the literature, were due to the short PL.

The AFC mean estimate was similar to those found by Lin \& Allaire (1977), Norman et al. (1996) and Jagannatha et al. (1998). However it was higher than the value obtained by Kulak et al. (1997a) and lower than that reported by Vercesi Filho et al. (2000).

AFC is directly related to age at conception, which reflects, among other factors, the management and feed made available to the heifer. The AFC mean estimate close to 28 months reflected the good conditions provided for the heifers, as well as attention to estrus detection.

Overall, the results indicated that cows staying and producing for more than two years after the first calving are economically profitable. NIPL was an exception because it depends on longer productive life to obtain positive values. Besides, high costs of the heifer up to the end of the first lactation reinforce the need to keep the animal for a longer time in the herd in order to generate revenues not only to cover costs but also to obtain higher net income. Therefore, a longer PL would provide a larger number of calvings than observed (2.30). It should be remarked that a longer PL only improves economic indexes if it is accompanied by good health, reproductive and productive performances.

Among the measures studied, EF is probably the most difficult to be understood by dairy farmers, because it is not expressed in monetary units. Traits expressed by monetary units would be the best indicators to visualize what remains after payments, and the economic measure they could count on to bear their commitments.

Table 3 shows the variance components and heritability estimates of the economic traits and productive life.

Heritability estimates (Table 3 ) ranged from 0.06 to 0.09 indicating a small contribution of additive genetic action or the importance of the reproductive and survival traits for the profitability measures. Estimates of heritability for these traits are usually low. The estimates obtained in this study are similar to those reported by Weigel et al. (1995a) and Weigel et al. (1997) and smaller than those reported by Lin \& Allaire (1977).

Although the small values for the estimates of heritability of these important economic traits, additive genetic variation is still present suggesting they could be improved by selection. Correlation studies among these traits would help to identify the easiest, the most available or the earliest (in the life of the animals) measure to be used for selecting animals. Table 4 shows gross and Spearman correlations between EBVs of the animals for the traits studied. The Spearman correlation estimates were used to compare sires using individual EBV ranked in decreasing order.

The gross and the Spearman correlation estimates were positive, ranging from moderate to high values and thus suggesting a direct linear relationship between variables. Comparisons of these results with others were hampered due to the scarcity of publications dealing with this subject in the literature.

Gross correlation estimates between LNI and EF and between IOFC and MY were higher than 0.80 indicating they were strongly related. Because LNI and EF are different expressions of the same variables, the resulting genetic correlation between them could be thought as a spurious estimate and should be not considered. Kulak et al. (1997b) obtained slightly higher values between LNI and EF (0.849). Cassell et al. (1993) reported similar results for MY and IOFC. The correlation estimate between EBVs of LNI and MY (0.809) indicated that the animals with high production had large net incomes. However, the rank correlation (0.623) between these traits indicated that using LNI or MY as selection criteria would not select the same animals. The Spearman correlation between LNI and IOFC was very high (0.937), indicating they rank animals in a similar way. This

Table 3 - Estimates of variance components and heritability $\left(h^{2}\right)$ of the economic traits of Holstein cows

\begin{tabular}{lccc}
\hline Trait & $\sigma^{2}{ }_{\mathrm{a}}$ & $\sigma_{\mathrm{e}}^{2}$ & $\mathrm{~h}^{2}$ \\
\hline LNI & $37,615.00$ & $52,5574.00$ & 0.07 \\
EF & 0.0015 & 0.015 & 0.09 \\
IOFC & $59,914.48$ & $633,813.05$ & 0.09 \\
NIPL & 0.162 & 2.573 & 0.06 \\
MY & $114,9509.14$ & $11,104,539.74$ & 0.09 \\
NI1 & $12,881.00$ & $157,921.00$ & 0.08 \\
IOFC1 & $13,272.00$ & $154,409.00$ & 0.08 \\
MY1 & $232,439.00$ & $2,639,378.00$ & 0.08 \\
PL & 809.64 & 9326.12 & 0.08 \\
\hline
\end{tabular}

$\sigma^{2}=$ additive genetic variance, $\sigma^{2}=$ environmental variance, $\mathrm{LNI}=$ lifetime net income, $E F=$ efficiency, $I O F C=$ milk income over feed costs, NIPL = net income per day of productive life, $M Y=$ lifetime milk yield, $\mathrm{NI} 1=$ net income at the end of first lactation, IOFC1 = milk income over feed costs from the first lactation minus the feed costs $M Y 1=$ milk yield at the end of the first lactation and $\mathrm{PL}=$ productive life. 
Table 4 - Spearman correlation (below diagonal) and gross correlation (above the diagonal) estimates between EBVs for the animals for the economic traits of Holstein cows

\begin{tabular}{|c|c|c|c|c|c|c|c|c|}
\hline & LNI & $\mathrm{EF}$ & IOFC & NIPL & MY & NI1 & IOFC1 & MY 1 \\
\hline LNI & & $0.849 *$ & $0.899 *$ & $0.651 *$ & $0.809 *$ & $0.494 *$ & $0.559 *$ & $0.470^{*}$ \\
\hline $\mathrm{EF}$ & $0.798 *$ & & $0.746^{*}$ & $0.897 *$ & $0.665 *$ & $0.627 *$ & $0.715^{*}$ & $0.625 *$ \\
\hline IOFC & $0.937 *$ & $0.708 *$ & & $0.609 *$ & $0.976^{*}$ & $0.301 *$ & $0.507 *$ & $0.474 *$ \\
\hline NIPL & $0.529 *$ & $0.822 *$ & $0.431 *$ & & $0.568 *$ & $0.552 *$ & $0.672 *$ & $0.635^{*}$ \\
\hline MY & $0.623 *$ & $0.508 *$ & $0.687^{*}$ & $0.407 *$ & & $0.210 *$ & $0.442 *$ & $0.458 *$ \\
\hline NI1 & $0.591 *$ & $0.658 *$ & $0.558 *$ & $0.588 *$ & $0.517 *$ & & $0.848 *$ & $0.724 *$ \\
\hline IOFC1 & $0.501 *$ & $0.511 *$ & $0.538 *$ & $0.428 *$ & $0.554 *$ & $0.892 *$ & & $0.931 *$ \\
\hline MY 1 & $0.346^{*}$ & $0.404 *$ & $0.399 *$ & $0.377 *$ & $0.598 *$ & $0.693 *$ & $0.821 *$ & \\
\hline
\end{tabular}

${ }^{*}=\mathrm{P}<0.0001 . \mathrm{LNI}=$ lifetime net income, $\mathrm{EF}=$ efficiency, IOFC = milk income over feed costs, NIPL = net income per day of productive life, MY $=$ lifetime milk yield, NI1 = net income at the end of first lactation, IOFC1 = milk income over feed costs from the first lactation minus the feed costs and MY $1=$ milk yield at the end of the first lactation.

correlation suggests IOFC as the most appropriate measure or the alternative choice of selection criteria, in order to maximize LNI. Besides, the required information to calculate IOFC is easily recorded in dairy farms.

The Spearman correlations estimates between LNI and EF and between LNI and MY were moderate ( 0.798 and 0.623, respectively) and similar to those obtained by Cassell et al. (1993) for MY and lifetime revenue traits. The major difference between LNI and EF is that the first is obtained by the difference and the second by the ratio of revenues and costs. LNI express the amount in monetary units that is left after the payment of the costs involved, while EF express the relationship of how much can be expected per amount invested. However, LNI and EF did not rank the animals in the same order, which means that animals that generate more profit, but with higher costs, were not always the most efficient in the herd, and vice-versa.

The estimates of correlation between EBVs of LNI and the traits measured in the first lactation (NI1, IOFC1 and MY1) were moderate $(<0.56)$, reflecting a positive relationship, albeit not as strong as those ( 0.58 to 0.63$)$ observed by Cassell et al. (1993). The rank correlation estimates between LNI and the traits NI1, IOFC1 and MY1 were higher for NI1 (0.591), when compared to IOFC1 (0.501) and MY1 (0.346), indicating that the use of first lactation traits as selection criteria rank animals in a different order than LNI. The expected genetic gains for LNI would be lower by using any of these traits than by using IOFC as the selection criterion.

The gross correlation estimates for EF with the other profitability measures were moderate to high (0.627 to $0.897)$, with similar pattern for the rank correlation estimates (0.404 to 0.849$)$, albeit slightly lower.

The gross correlation estimates between IOFC and each one of the other traits showed a large variation $(0.301$ to 0.976$)$ as did the Spearman correlation estimates $(0.399$ to 0.937 )
The gross correlation estimate between IOFC and MY was high (0.976), but the Spearman correlation was lower than that value (0.687). These results indicate that the same animals would not be ranked in a similar order by using these traits as the selection criteria. The relationships between IOFC1 and MY1 were similar to those described for IOFC and MY1.

The largest rank correlation estimates for early measures using the first lactation traits were observed between LNI and NI1 (0.591), followed by LNI and IOFC1 (0.501) and LNI and MY1 (0.346). These results indicate differences between selecting for milk yield, especially with MY1 as the criterion, and selecting for LNI. Assuming the selection of dairy cows is done in the first lactation, MY1 will have a remarked impact on determining which animals will remain in the herd, to be the parents of the following generation. The value of 0.623 for the rank correlation estimate between LNI and MY indicates that animals with higher breeding values for MY will not be necessarily those with higher LNI EBVs. Meanwhile, it should be noted that EF and the first lactation traits had larger correlation estimates between EBVs (LNI 0.627, IOFC1 0.715, MY1, 0.625 and NIPL 0.897) than did LNI with the same traits. A similar pattern was observed for the Spearman correlation between the same traits, although the estimates were lower. These results suggest that if earlier profitability measures are important as selection criteria, the selection objective can be EF instead of LNI.

Figure 1 shows the change in the rank position of sires according to Spearman correlation between LNI and IOFC. Despite the high rank correlation between sires for these traits $(94 \%)$, about $20 \%$ of sires classified at the upper $10 \%$ (decile 1) for LNI shifted to decile 2 and $2 \%$ to decile 3. About $78 \%$ of sires in the top $10 \%$ would be the same for both traits.

However, according to the criterion EF, about $64 \%$ of the sires classified among the upper $10 \%$ were coincident with those selected by LNI. About $16 \%$ of the animals 
shifted to decile $2,4 \%$ to decile $3,7 \%$ to decile $4,2 \%$ to decile 5 and $7 \%$ to decile 6 or higher, that is, the sires included in deciles 6 or higher would be classified among the lower $50 \%$.

If NIPL is to be used as the selection criterion, only 42 $\%$ of the top $10 \%$ sires would rank similar to LNI, while the other $58 \%$ would have shifted to other deciles.

Figure 2 shows that selecting the top $10 \%$ bulls by LNI, only $44 \%$ would be ranked by NI1 and only $36 \%$ by IOFC 1 or MY1.

Progeny tests of bulls usually gives a considerable importance to the traits included in MY1 (PY, FY and MY).
Nonetheless, the results from this study denote a coincidence between bulls selected by LNI and by MY1, of at least onethird. Therefore it seems to be important to include some measures of profitability in the evaluation of bulls. Approximately $22 \%$ of the animals considered superior according to LNI moved to decile 3 of IOFC1. That is, they would be ranked among those animals included in the 20 to $30 \%$ and probably would not be selected as sires.

Figure 3 presents the changes and coincidence between ranking of sires in deciles for the traits MY and LNI, with at least $42 \%$ of the bulls coinciding in decile 1 . About $24 \%$ of

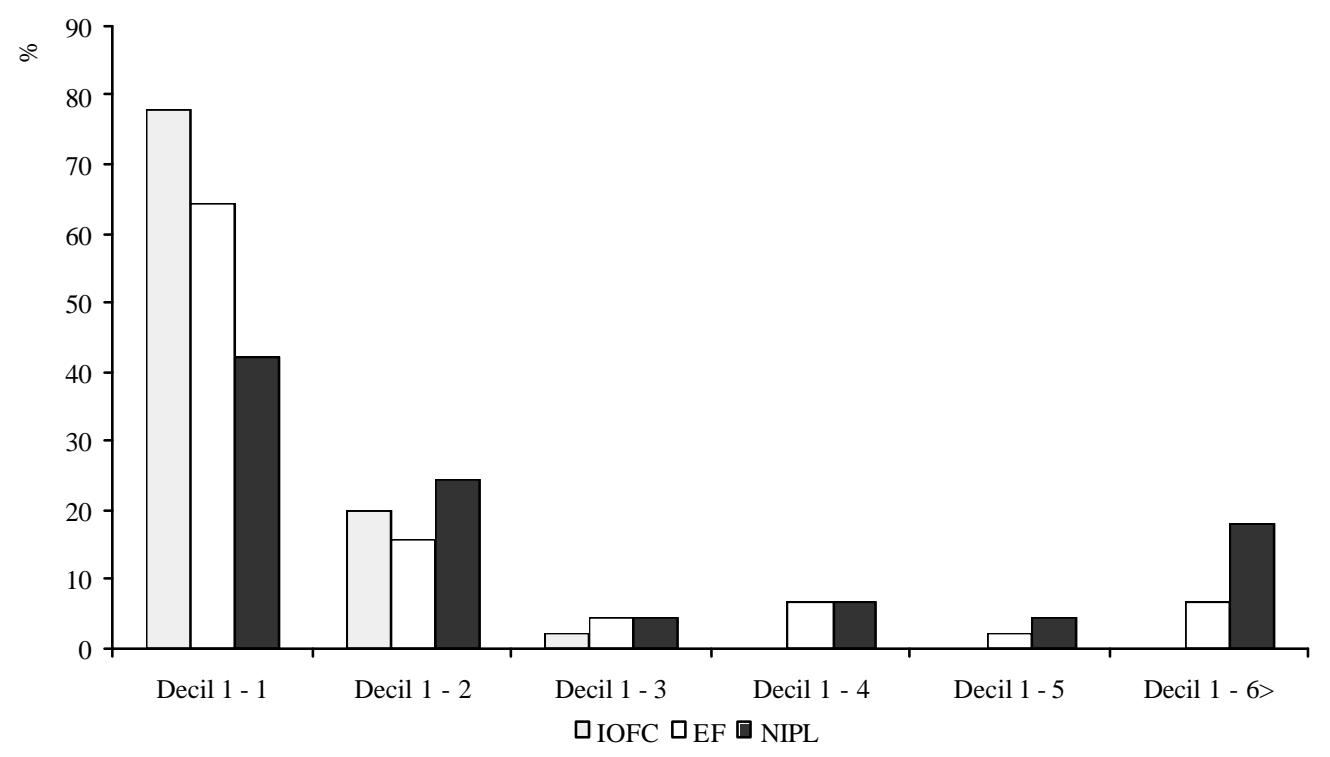

Figure 1 - Coincidence (Decile 1-1) and changes in rank of bulls classified in deciles (Decile 1-2 to Decile 1-6>) for the selection criteria milk income over feed costs (IOFC), Efficiency (EF) and net income per day of productive life (NIPL), considering lifetime net income (LNI) as anchor.

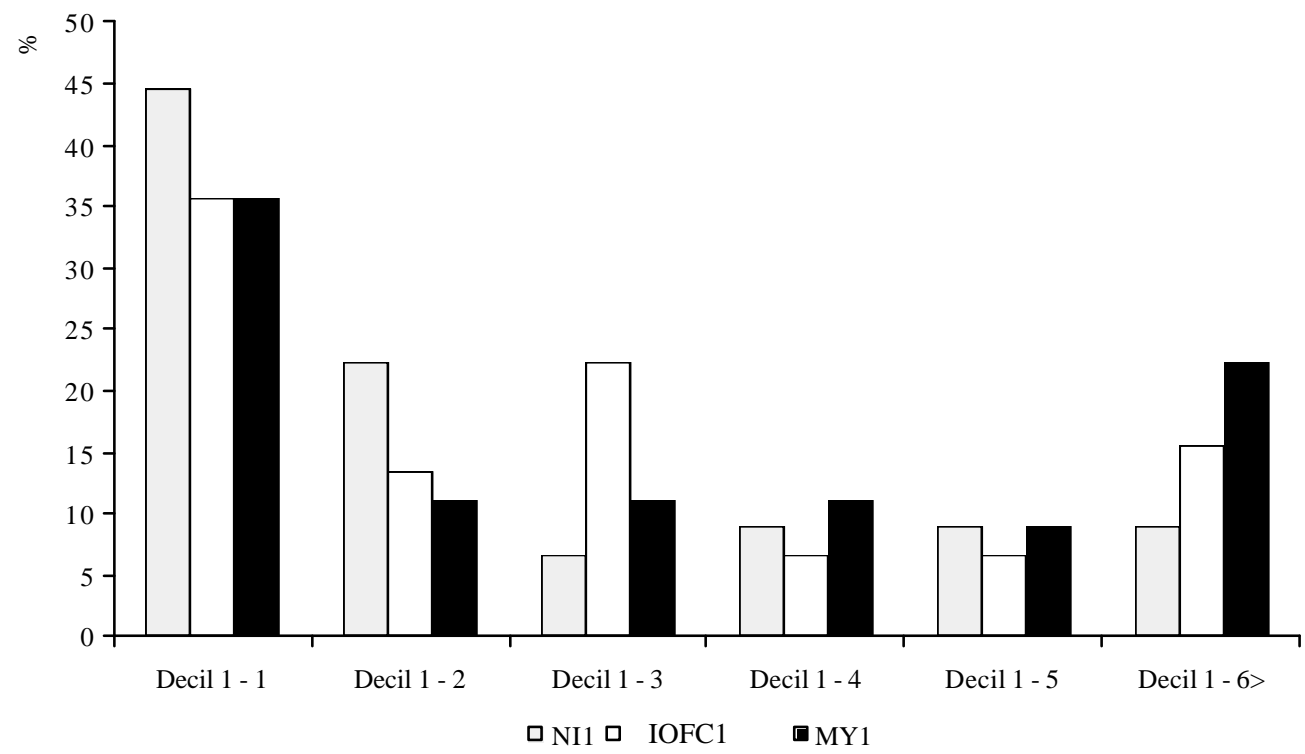

Figure 2 - Coincidence (Decile 1-1) and changes in rank of bulls classified in deciles (Decile 1-2 to Decile 1-6>) for the selection criteria net income at end of the first lactation (NI1), milk income over feed costs at the end of the first lactation (IOFC1) and milk yield in the first lactation (MY1), considering lifetime net income (LNI) as anchor. 


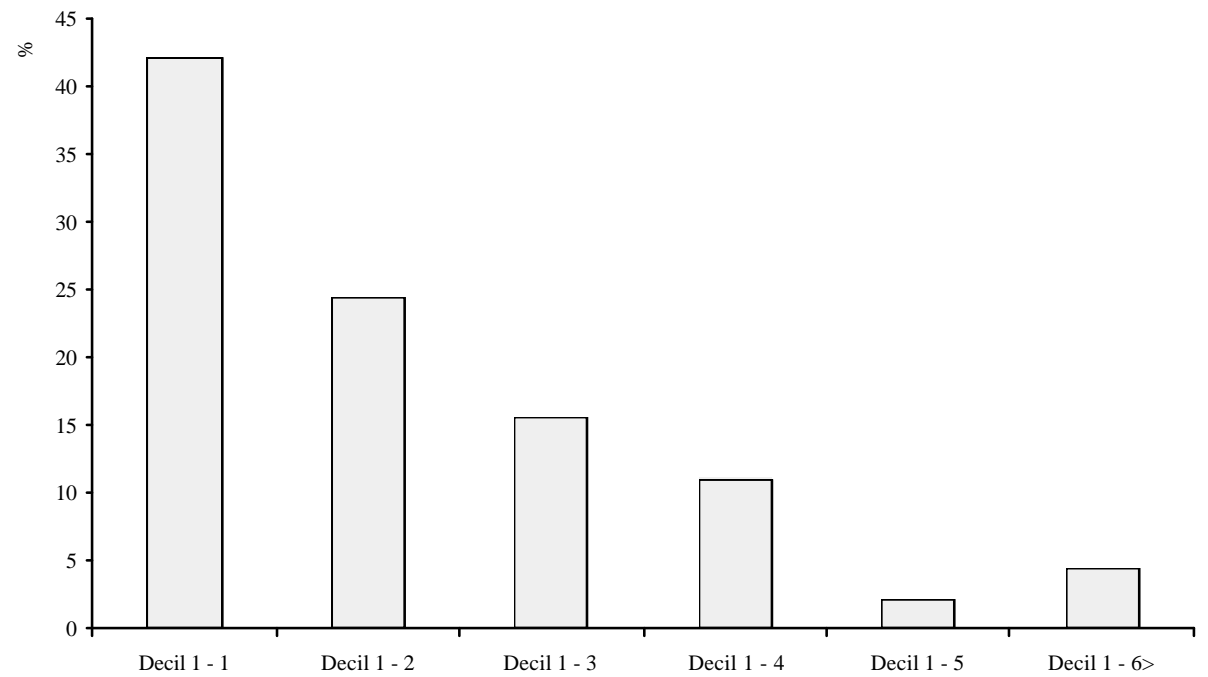

Figure 3 - Coincidence (Decile 1-1) and changes in rank of bulls classified in deciles (Decile 1-2 to Decile 1-6>) for the selection criteria lifetime milk yield (MY), considering lifetime net income (LNI) as anchor.

the bulls that would be ranked in decile 1 for LNI were in decile 2 for MY. Because the number of bulls approved as sires is usually small, those ranked in the second decile would have a minor chance to be selected.

In summary, despite that LNI allows for a more complete evaluation of the profitability of dairy cows, taking into account the cost benefit ratio of recording additional data and the high correlation estimates (0.899 and 0.937, respectively for Gross and Spearman correlations), IOFC is the best profitability measure and combines the ease of calculation with the least amount of information to be collected and high correlation with the breeding objective (LNI). However IOFC is a lifetime measure and thus needs a longer time to be measured.

The measures taken early in the life of the animal (NI1, IOFC1 and MY1) did not appear to be appropriate as selection criteria for LNI, because they did not rank the animals in similar orders.

Among the early measures studied, IOFC1 could be employed as selection criterion. This trait may be included in the evaluations of sires in progeny test.

\section{Conclusions}

LNI was the best profitability measure evaluated is this study. The Spearman correlation between LNI and IOFC was very high, indicating they rank animals in a similar way. This correlation suggests IOFC as the most appropriate measure or the alternative choice of selection criteria, in order to maximize LNI. Besides, the required information to calculate IOFC is easily recorded in dairy farms.
The traits measured in the first lactation do not seem appropriate as selection criteria for economic worth of dairy cows. Among them, NI1 was the most efficientprofitability measure, but it would be easier to record data to calculate IOFC 1 . The profitability measures were affected by the short productive life of the animals in the herds.

Selection based on different profitability measures would not result in similar ranking of sires.

\section{Literature Cited}

BARWICK, S. Introducing economics to modern animal breeding. In: HAMMOND, K.; GRASER, H-U.; MCDONALD, C.A. (Eds.) Animal breeding: the modern approach. Sidney: Post Graduate Foundation in Veterinary Science, 1992. p.121-140.

BOLDMAN, K.G.; KRIESE, L.A.; Van VLECK, L.D. et. al. A manual for use of MTDFREML: a set of programs to obtain estimate of variances and covariances. Department of Agriculture Research Service, Lincoln, 1993. 120p.

CALO, L.L.; MCDOWELL, R.E.; Van VLECK, L.D. et al. Genetic aspects of beef production among Holstein-Friesians pedigree selected for milk production. Journal of Animal Science, v.37, p.676-682, 1973.

CARDOSO, V.L.; NOGUEIRA, J.R.; Van ARENDONK, J.A.M. Optimal replacement and insemination policies for Holstein cattle in the Southeastern region for Brazil: the effect of selling animals for production. Journal of Dairy Science, v.82, p.1449-1458, 1999a.

CARDOSO, V.L.; NOGUEIRA, J.R.; Van ARENDONK, J.A.M Optimum replacement and insemination policies for crossbred cattle (Holstein x Zebu) in the South-east region of Brazil. Livestock Production Science, v.58, p.95-105, 1999 b.

CASSELL, B.G.; SMITH, B.B.; PEARSON, R.E. Influence of herdlife opportunity and characteristics of cows and herds on different net income parameters. Journal of Dairy Science, v.76, p.1182-1190, 1993.

DE HAAN, M.H.A.; CASSELL, B.G.; PEARSON, R.E. et al. Relationships between net income, days of productive life, production and linear type traits in grade and registered Holsteins. Journal of Dairy Science, v.75, p.3553-3561, 1992. 
GILL, G.S.; ALLAIRE, F.R. Relationship of age at first calving, days open, days dry and herdlife to a profit function for dairy cattle. Journal of Dairy Science, v.59, p.1131-1139, 1976.

GODDARD, M. Breeding objectives for dairy cattle. In: HAMMOND, K.; GRASER, H-U.; MCDONALD, C.A. (Eds.) Animal breeding: the modern approach. Sidney: Post Graduate Foundation in Veterinary Science, 1992. p.177-182.

HAMMOND, K. The modern breeding approach. In: HAMMOND, K.; GRASER, H-U.; MCDONALD, C.A. (Eds.) Animal breeding: the modern approach. Sidney: Post Graduate Foundation in Veterinary Science, 1992. p.13-26.

ISAACS, S.; FOLEY, D. Kentucky dairy enterprises: 1991 costs and returns. Lexington: Agricultural Economics, 1993 (Extension Report, 103).

JAGANNATHA, S.; KEOWN, J.F.; Van VLECK, L.D. Estimation of relative economic value for herd life of dairy cattle from profile equations. Journal of Dairy Science, v.81, p.1702$1708,1998$.

KLASSEN, D.J.; MONARDES, H.G.; JAIRATH, L. et al. Genetic correlation between lifetime production and linearized type in Canadian Holsteins. Journal of Dairy Science, v.75, p.22722282, 1992.

KULAK, K.K.; DEKKERS, J.C.M.; McALLISTER, A.J. et al. A.J. Relationship of early performance traits to lifetime profitability in Holstein cows. Canadian Journal of Animal Science, v.77, p.617-624, 1997a.

KULAK, K.K.; DEKKERS, J.C.M.; McALLISTER, A.J. et al. A.J. Lifetime profitability measures for dairy cows and their relationships to lifetime performance traits. Canadian Journal of Animal Science, v.77, p.609-616, 1977b.

LIN, C.Y.; ALLAIRE, F.R. Relative efficiency of selection methods for profit in dairy cows. Journal of Dairy Science, v.60, p.1970-1978, 1977.

McALLISTER, A.J. Costs and prices in Kentucky dairy farms. Kentucky: University of Kentucky, 2000. (Comunicação pessoal).

NORMAN, H.D.; POWELL, R.L.; WRIGHT, J.R. et al. Phenotypic relationship of yield and type scores from first lactation with herd life and profitability. Journal of Dairy Science, v. 79, p.689-701, 1996.
PEARSON, R.E.; FREEMAN, A.E. Effect of female culling and age distribution of the dairy herd on profitability. Journal of Dairy Science, v.56, p.1459-1471, 1973.

PEARSON, R.E.; MILLER, R.H. Economic definition of total performance, breeding goals and breeding values for dairy cattle. Journal of Dairy Science, v.64, p.857-869, 1981.

RENKEMA, J.A.; STELWAGEN, J. Economic evaluation of replacement rates in dairy herds. I. Reduction of replacement rates through improved health. Livestock Production Science, v.6, p.15-27, 1979.

STATISTICAL ANALYSIS SYSTEM - SAS. User's guide : statistics. Version 6. 4.ed. Cary: SAS Institute, 1996. (CD-ROM).

SHORT, T.H.; LAWLOR, T.J. Genetic parameters of conformation traits, milk yield, and herd life in Holsteins. Journal of Dairy Science, v. 75, p.1987-1998, 1992.

TIGGES, R.J.; PEARSON, R.E.; VINSON, W.E. Prediction of lifetime net income from first lactation production and individual type traits in Holstein cows. Journal of Dairy Science, v.69, p.204, 1986.

Van ARENDONK, J.A.M. Use of profit equations to determine relative economic value of dairy cattle herd and production from field data. Journal of Dairy Science, v.74, p.1101-1107, 1991.

VERCESI FILHO, A.E.; MADALENA, F.E.; FERREIRA, J.J. et al. Pesos econômicos para seleção de gado de leite. Revista Brasileira de Zootecnia, v. 29, p. 145-152, 2000.

WEIGEL, D.J.; CASSELL, B.G.; HOESCHELE, I. et al. Multiple-trait prediction of transmitting abilities for herd life and estimation of economic weights using relative net income adjusted for opportunity cost. Journal of Dairy Science, v.78, p.639-647, 1995a.

WEIGEL, D.J.; CASSELL, B.G.; PEARSON, R.E. Adjustment of a net income function for opportunity cost of postponed replacement on a lactation basis. Journal of Dairy Science, v.78, p.648-654, 1995b.

WEIGEL, D.J.; CASSELL, B.G.; PEARSON, R.E. Prediction of transmitting abilities for productive life and lifetime profitability from production, somatic cell count, and type traits in milk markets for fluid milk and cheese. Journal of Dairy Science, v.80, p.1398-1405, 1997.

WELLER, J.I. Economic aspects of animal breeding. London: Chapman \& Hall, 1994. 244p. 